\title{
ACTION OF PERACETIC ACID ON ESCHERICHIA COLI AND STAPHYLOCOCCUS AUREUS IN SUSPENSION OR SETTLED ON STAINLESS STEEL SURFACES
}

\author{
Leo Kunigk*; Maria C.B. Almeida \\ Departamento de Engenharia Química e de Alimentos, Escola de Engenharia Mauá, São Caetano do Sul, SP, Brasil
}

Submitted: May 04, 2000; Returned to authors for corrections: August 16, 2000; Approved: January 18, 2001

\begin{abstract}
The efficiency of a commercial peracetic acid sanitizer on destruction of Staphylococcus aureus and Escherichia coli was evaluated using two distinct methods. The first method is the AOAC suspension test and the second is a method proposed by one of the authors in which the microbial cells are settled on a stainless steel surface and then treated with the sanitizer. The results showed that when in suspension $S$. aureus was more resistant to the sanitizer than E. coli. When $S$. aureus was settled on the stainless steel surface, the contact time between the sanitizer and the microorganisms to attain a $6.5 \log$ reduction in the number of viable cells was three times greater than when the cells were in suspension.
\end{abstract}

Key words: peracetic acid, Staphylococcus aureus, Escherichia coli, stainless steel surface, sanitizers

\section{INTRODUCTION}

Contaminating microorganisms in food industries may have several origins, including raw materials, workers, equipment and containers. If these microorganisms are not destroyed during processing, they can grow during production, distribution or commercialization of the food, reducing the quality. If the contamination is not completely eliminated from the food processing plant, future productions may be affected. Removal of the contaminant microbiota from food contact surfaces can be achieved using efficient sanitizers. Therefore, the efficiency of sanitizers at use conditions must be well determined. Different methods are available for this evaluation including the suspension method of AOAC (1). However, this method does not take into account the fact that the activity of a sanitizer depends on the physical situation of the microbial cells. When the microorganisms are settled on or adhered to the equipment surface, they can be protected by the irregularities of the surface, hampering the action of the sanitizer.

Peracetic acid (PAA) presents many advantages when compared to sodium hypochloride, the most common sanitizer in Brazil. One important advantage is that it does not produce toxic residues when decomposed and therefore does not affect either the final product or the waste treatment process. PAA can be utilized over a wide temperature spectrum $\left(0\right.$ to $\left.40^{\circ} \mathrm{C}\right)(6)$, in clean in place (CIP) processes and in carbon dioxide saturated environments (3). PAA can also be used with hard water. In addition, protein residues do not affect its efficiency. Until now, no microbial resistance to PAA was reported. It is efficient over a wide spectrum of $\mathrm{pH}$, from 3.0 to $7.5(2,7,3)$. As this sanitizer is relatively new, it is not known whether the efficiency to destroy microorganisms settled on surfaces is similar to sodium hypochlorite.

It is important to observe that true biofilms, including the types studied in aquatic systems, medical devices and biofauling, may take several days, weeks or even months to develop. Surfaces that get in contact with food rarely are left without some type of cleaning and sanitizing treatment for more than 24 hours. Thus, according to Zottola (9), biofilms formed during food processing are not true or classical biofilms.

The objective of the present study was to evaluate the activity of PAA over planktonic cells present on a stainless steel surface. These are free-living cells and not attached to the surface. A short exposure time of the surface to cultures of Staphylococcus

\footnotetext{
* Corresponding author. Mailing address: Departamento de Engenharia Química e de Alimentos, Escola de Engenharia Mauá, Estrada das Lágrimas, 2035, CEP 09580900, São Caetano do Sul, SP, Brasil. Fax: (+5511) 4239-3131. E-mail: kunigk@ maua.br
} 
aureus and Escherichia coli was used to achieve this contamination. A commercial sanitizer, based on PAA, was used to evaluate the efficiency of removal of these contaminants from a stainless steel device specially designed for this study.

\section{MATERIALS AND METHODS}

Escherichia coli and Staphylococcus aureus isolated from "Minas Frescal" cheese by Jurkiewicz (4) were used in this work. Suspensions of each bacterium were prepared in sterile saline peptone solution $(\mathrm{NaCl} 8.5 \mathrm{~g} / \mathrm{L}$, peptone $10.0 \mathrm{~g} / \mathrm{L})$, using fresh cultures grown on Plate Count Agar medium (PCA) at $36^{\circ} \mathrm{C}$ for 24 hours. The suspensions presented $40 \%$ transmittance at 610 $\mathrm{nm}$, which corresponded to $10^{7}-10^{8} \mathrm{CFU} / \mathrm{mL}$.

One milliliter of the suspension was transferred to test tubes containing $8 \mathrm{~mL}$ peracetic acid solution (40 or $60 \mathrm{mg} / \mathrm{L}$ ). These sanitizer solutions were prepared with a commercial formulation of peracetic acid sanitizer containing $15 \%$ peracetic acid and $30 \%$ hydrogen peroxide (Diversey-Lever). The tubes were maintained at $25^{\circ} \mathrm{C}$ in a thermostatic water bath. At every one minute, one tube was removed from the bath and $1.0 \mathrm{~mL}$ of a $100 \mathrm{~g} / \mathrm{L}$ sodium thiosulphate $\left(\mathrm{Na}_{2} \mathrm{~S}_{2} \mathrm{O}_{3}\right)$ solution was added to neutralize the peracetic acid. The number of $\mathrm{CFU} / \mathrm{mL}$ in each tube was determined by pour-plating the suspension on PCA medium and incubating at $36^{\circ} \mathrm{C}$ for 48 hours. The experiments were repeated three times. Results correspond to average counts for each contact time between the sanitizer and the microorganisms.

Fig. 1 shows the stainless steel device designed to study the action of the sanitizer on microbial cells settled on a surface
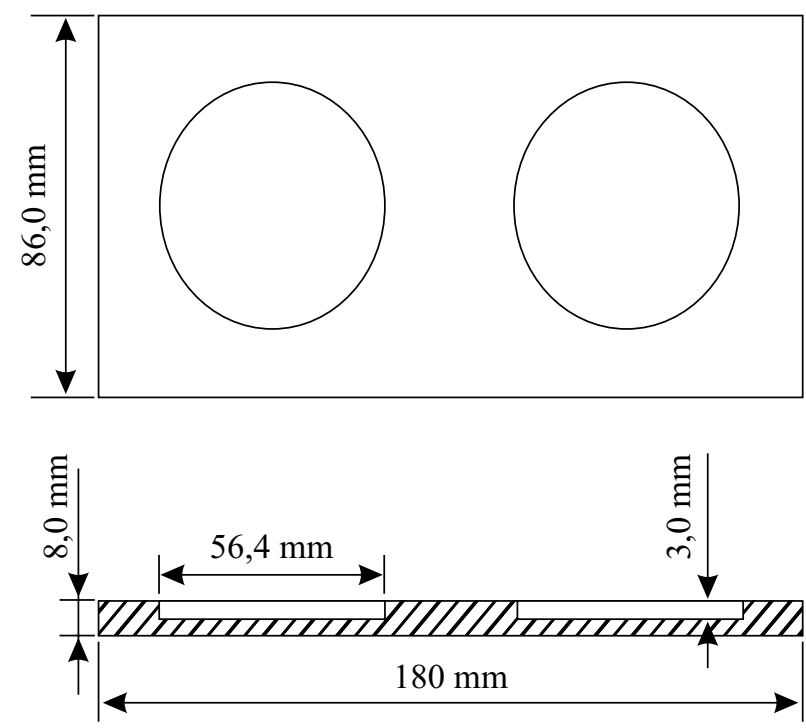

Figure 1. Stainless steel device used in the evaluation of peracetic acid efficiency.
(5). The finishing of the cavities was the same required by the food industries. Six $\mathrm{mL}$ of the suspension of $S$. aureus, containing $10^{8} \mathrm{CFU} / \mathrm{mL}$ was aseptically added to each cavity of the device. The device was covered with a large Petri dish and incubated at $36^{\circ} \mathrm{C}$ for 30 minutes. The suspensions were then carefully removed from the cavities and the sanitizer solution was added to one of them. The contact time between the surface and the microorganisms was 2, 4, 6, 8, 10, 12, 14, 16, 22, 24, 30 and 35 minutes. At the end of each contact time, the sanitizer solution was removed from the cavity and immediately filled with a $100 \mathrm{~g} / \mathrm{L}$ solution of $\mathrm{Na}_{2} \mathrm{~S}_{2} \mathrm{O}_{3}$. After 5 minutes, this solution was removed and the number of viable microorganisms settled on the surface of each cavity was determined by the swab method (8). The difference between the counts in the two cavities represents the efficiency of the sanitizer. Each contact time was tested three times. Results correspond to the average of the counts.

\section{RESULTS AND DISCUSSION}

Fig. 2 shows the efficiency of peractic acid on $E$. coli and $S$. aureus when in suspension. When $E$. coli was treated with peracetic acid solution at $60 \mathrm{mg} / \mathrm{L}$ at $25^{\circ} \mathrm{C}$, a reduction of $8.0 \mathrm{log}$ cycles was attained in 3.1 minutes of contact. When the concentration of the peracetic acid solution was reduced to $40 \mathrm{mg} / \mathrm{L}, 4.0$ minutes were necessary to attain the same destruction level. S. aureus was more resistant than $E$. coli. For this microorganism and a peracetic acid solution at $40 \mathrm{mg} / \mathrm{L}$, only $6.2 \log$ cycle reduction was achieved in 10 minutes of contact. Fig. 2 also shows that the destruction kinetics can be represented by first order equations, which are shown in Table 1. This Table also shows the time necessary to attain one $\log$ cycle reduction ( $\mathrm{D}$ values).

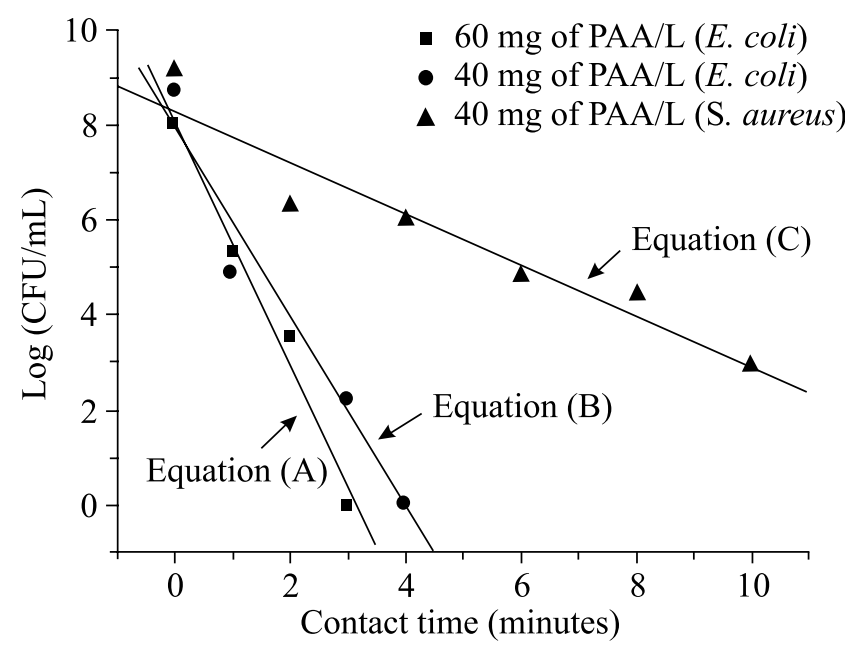

Figure 2. Action of peracetic acid on E. coli and S. aureus in suspension at $25^{\circ} \mathrm{C}$. 
Table 1. Linear regressions that represent the destruction kinetics of E. coli and S. aureus in suspension and exposed to peracetic acid (PAA).

\begin{tabular}{lclccc}
\hline Bacteria & $\begin{array}{c}\text { PAA concentration } \\
(\mathrm{mg} / \mathrm{L})\end{array}$ & \multicolumn{1}{c}{ Linear regression } & Determinent coefficient $\left(\mathrm{r}^{2}\right)$ & $\mathrm{D}(\mathrm{min})$ & Equation \\
\hline E. coli & 60.0 & $\log (\mathrm{CFU} / \mathrm{ml})=8.1-2.58 \mathrm{x} \theta$ & 0.985 & 0.39 & $(\mathrm{~A})$ \\
E. coli & 40.0 & $\log (\mathrm{CFU} / \mathrm{ml})=8.0-2.01 \times 0$ & 0.959 & 0.50 & $(\mathrm{~B})$ \\
S. aureus & 40.0 & $\log (\mathrm{CFU} / \mathrm{ml})=8.3-5.41 .10^{-1} \mathrm{x} \theta$ & 0.921 & 1.85 & $(\mathrm{C})$ \\
\hline
\end{tabular}

$\theta=$ Contact time between the sanitizer and the microorganisms.

Table 2. Linear regressions that represent the decimal reduction (DR) of S. aureus in suspension and settled on a stainless steel surface, using $40 \mathrm{mg} / \mathrm{L}$ peracetic acid solution

\begin{tabular}{lcccc}
\hline Conditions & Contact time interval $(\mathrm{min})$ & Linear regression & Determinent coefficient $\left(\mathrm{r}^{2}\right)$ & Equation \\
\hline Suspension & 2 to 10 & $\mathrm{DR}=1.45+4.55 \times 10^{-1} \mathrm{x} \theta$ & 0.955 & (D) \\
Surface & 2 to 25 & $\mathrm{DR}=4.34+3.70 \times 10^{-3} \times \theta$ & 0.012 & (E) \\
Surface & 25 to 35 & $\mathrm{DR}=-5.63+3.90 \times 10^{-1} \mathrm{x} \theta$ & 0.900 & (F) \\
\hline
\end{tabular}

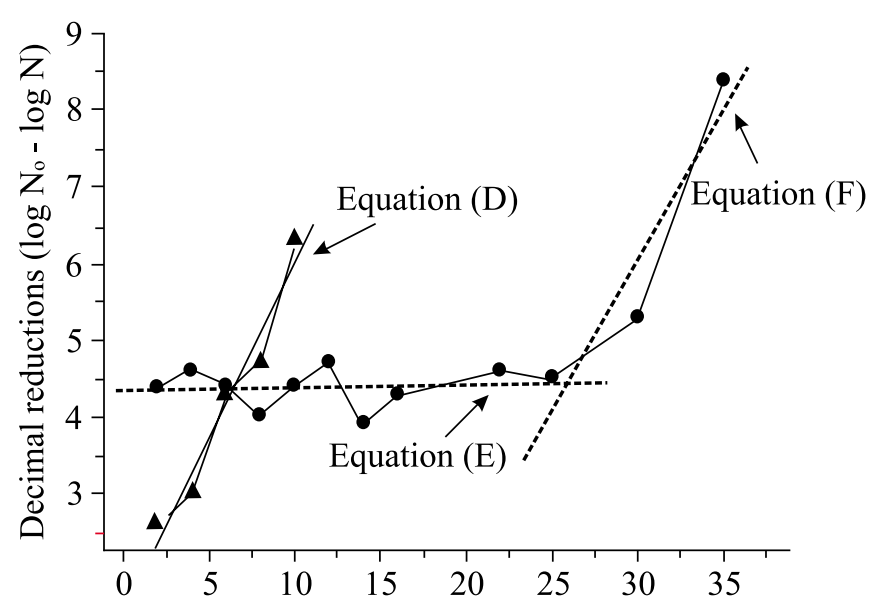

Contact time between the sanitizer and the micoorganism (minutes)

Figure 3. Action of peracetic acid $(40 \mathrm{mg} / \mathrm{L})$ on $S$. aureus in suspension $(\mathbf{\Delta})$ and settled on the stainless steel surface at $25^{\circ} \mathrm{C} \pm 1^{\circ} \mathrm{C}(\bullet)$.

$\mathrm{N}_{\mathrm{o}}=$ initial number of viable cells; $\mathrm{N}=$ final number of viable cells.

Fig. 3 shows the results obtained when S. aureus in suspension and settled on a stainless steel surface was treated with a $40 \mathrm{mg} / \mathrm{L}$ peracetic acid solution.

When the microorganisms were in suspension, the peracetic acid efficiency was quite different from that observed when the microorganisms were settled on the stainless steel surface. In this last condition, the destruction kinetics may be represented by two different equations, one corresponding to 2-25 minutes of contact and the second to 25-35 minutes of contact. Kunigk (5) observed similar results for Gordona sp., a microorganism isolated in a brewery. This author (5) reported that the efficiency of peracetic acid was constant in the first 30 minutes of contact, but increased afterwards.

Table 2 shows the linear regressions for both conditions (cells in suspension and settled on a surface) when $S$. aureus was treated with a $40 \mathrm{mg} / \mathrm{L}$ peracetic acid solution.

Equation (D) and equation (F), in Table 2, represent the relation between the time and the decimal reduction in $95.5 \%$ and $90.0 \%$, respectively. For equation (E), the statistical analysis showed that within a confidence level of $95 \%$ and for the 2-25 minutes contact time, the efficiency of the sanitizer was constant, causing a reduction of $4.3 \log$ cycles.

Fig. 3 and Table 2 show that, when the bacterial cells were settled on the stainless steel surface, the specific destruction rate constant $\left(3.90 \times 10^{-1} \mathrm{~h}^{-1}\right)$ for 25-35 minutes contact time was similar to the constant obtained for cells in suspension (4.55 $\mathrm{x}$ $\left.10^{-1} \mathrm{~h}^{-1}\right)$, at $95 \%$ confidence level. In a previous study, working with Gordona sp., Kunigk (5) came to a similar conclusion.

The results obtained for cells settled on the stainless steel device shown in Fig.1 are a consequence of mechanical barriers that hinder the action of the sanitizer. Among these barriers, the surface irregularities play the most important role, followed by the external layer of PAA-destroyed cells. All these barriers are absent when the microorganisms are in suspension. Consequently, the destruction rate when the cells are in suspension is higher in this condition than when the microorganisms are settled on a surface.

\section{ACKNOWLEDGEMENTS}

The authors thank Dr. Walter Borzani for his critical review of the manuscript and to APV for providing the correct finishing of the stainless steel device used in the study. Fundação de Amparo à Pesquisa do Estado de São Paulo (FAPESP) and Instituto Mauá de Tecnologia supported this study. 


\section{RESUMO}

\section{Ação do ácido peracético na destruição de} Staphylococcus aureus e Escherichia coli em suspensão ou sedimentados sobre uma superfície de aço inoxidável

A eficiência de um sanificante comercial à base de ácido peracético na destruição de Staphylococcus aureus e Escherichia coli foi avaliada apregando-se dois métodos distintos. O primeiro corresponde ao método da suspensão da AOAC e o segundo ao método desenvolvido por um dos autores, no qual a eficiência de sanificantes é avaliada em culturas microbianas aplicadas à uma superfície de aço inoxidável com o mesmo grau de acabamento das superfícies encontradas nas indústrias de alimentos. Os resultados indicaram que $S$. aureus foi mais resistente ao sanificante que $E$. coli, quando em suspensão. Quando $S$. aureus encontrava-se sedimentando sobre uma superfície de aço inoxidável, o tempo de contato entre sanificante e microrganismos para reduzir a população 6,5 ciclos logaritmos foi 3 vezes maior do que quando esses microrganismos estavam em suspensão.

Palavras-chave: ácido peracético, Staphylococcus aureus, Escherichia coli, superfície de aço inoxidável, sanificantes

\section{REFERENCES}

1. Association of Official Analytical Chemists Official Methods of Analysis. Williams, S. (ed). AOAC, Arlington, 1984, p.70-71.

2. Block, S.S. Peroxygen compounds. In: Block, S.S. Disinfection, Sterilization, and Preservation. Lea \& Febiger, Philadelphia, 1991, p.167181.

3. Jurado, J. The stability of disinfectants used in brewery CIP. MBAA Technical Quaterly, 30:58-63, 1993.

4. Jurkiewicz, C.H. Avaliação das características microbiológicas, fisicoquímicas e sensoriais de queijo minas frescal eleborado com culturas probióticas de Lactobacillus acidophilus. São Paulo, 1999, 133p. (Ph.D Thesis. Faculdade de Ciências Farmacêuticas. USP).

5. Kunigk, L. Ação do ácido peracético sobre microrganismos contaminantes do processo cervejeiro. São Paulo, 1998, 130p. (Ph.D. Thesis. Faculdade de Ciências Farmacêuticas. USP).

6. Leaper, S. Influence of temperature on the synergistic sporicidal effect of peracetic acid plus hydrogen peroxide on Bacillus subtilis SA (NCA 7252). Food Microbiol., 1: 199-203,1984.

7. Lenahan, R.J. - Peroxyacetic acid: The new generation sanitizer. $M B A A$ Technical Quaterly, 29:53-56, 1992.

8. Snyder Jr., O.P. - HACCP - An Industry Food Safety Self-Control Program - Part V Food. Dairy, Food Environ. Sanitation. 5:291-295, 1992

9. Zottola, E.A. - Special Techniques for Studying Microbial Biofilms in Food Systems. In: Tortorello, M.L. and Gendel, S.M (eds). Food Microbiological Analysis. Marcel Dekker, Inc. New York, 1997, p.315346. 